\title{
From 'Trial by media' to 'Media/trial'. The interaction between news media and justice: the production of news about the genocide trial against Frans van Anraat
}

\author{
Rob Leurs \\ Utrecht University \\ E-mail: R.H.Leurs@uu.nl
}

Abstract

\begin{abstract}
In 2005, Dutch businessman Frans van Anraat was brought to court on charges of illegally supplying chemicals to Saddam Hussein; these chemicals were processed into poison gases with which thousands of Kurdish civilians were killed in 1988. In order to answer the question how truth and morality were encoded in news about this genocide trial, I've held semistructured interviews with stakeholders in the production of journalistic reports. A discourse analysis, based on Laclau and Mouffe (1985), of the interview results shows a binary position in dealing with journalistic media between on the one hand victims, lawyers, and journalists and on the other persons from the Public Prosecution Service and members of the House of Representatives (= Dutch Lower House). The first group has founded its involvement in producing news reports on the assumptions that media is able to show the thruth, and that this generates justice. In other words, victims, lawyers, and journalists see media as guardians of a deeper (moral) truth.
\end{abstract}

Contrary, even before the trial the second group, consisting of the Public Prosecution Service and members of the House of Representatives, has actively developed media strategies designed to define what the trial should include (in both a legal and a moral sense), what the events underlying the trial are, what the construction of criminality is and those who belong to it, etc. These media strategies have, as was explicitly intended, influenced the legal process.

These findings have implications for our ideas of the relation between media and justice: the conventional idea of "trial by media' must be supplemented by the concept of 'media/trial'. 'Trial by media' implies that media and justice function parallel to but independently of each other: media negatively impact an individual's reputation by creating the notion of guilt prior to and/or independently of the court's verdict. The concept of 'media/trial' goes beyond that: it assumes that media can be used strategically to influence the outcome of a trial. The case

Data de submissão: 2016-03-31. Data de aprovação: 2016-05-17. 
of Frans van Anraat does not stand alone: dia are actively employed by e.g. Public expert interviews have shown that also in Prosecution Services to steer judicial proother European and American trials me- cesses.

Keywords: crime news; discourse theory; expert interviews; journalism; litigation PR; media production; media theory; media/trial; participation culture; trial by media.

Nothing about evil is without contradiction. Nothing about evil is certain. Roger Silverstone ${ }^{1}$

\section{Context}

$\mathrm{M}^{\mathrm{s}}$

EDIA and justice have a complex relationship: trials are expected to be held without unneccessary external interference and (journalistic) media must aim to report unhindered and motivated by the principle of 'objectivity'. This often poses a mutual tension that sometimes results in 'trial by media'. This concept indicates that media and justice are simultaneously present but operate relatively autonomously of each other: media influence reputations of suspects or other participants in a trial in anticipation of and/or independently of the verdict by judges. The trial against the murder suspect O.J. Simpson is a classic example: despite the acquittal a large part of the American people believes that he was guilty of a double murder. ${ }^{2}$

However, the relationship between media and justice can be even more complex. The case of genocide suspect Frans van Anraat shows that participants in a trial also employ media strategically in order to influence legal processes. This also occurs in other legal cases, for example with engaging media to recruit potential (criminal) witnesses: this requires the coordination of ideas about which witness statements are legally desirable, whom may make such statements and how media are employed to persuade individuals to actually act as witnesses. In cases like these, media and justice no longer operate relatively independently. Parallel to 'trial by media', this mutual influence can be understood in terms of 'media/trial'.

1. Silverstone, R. (2007). Media and morality. On the rise of the mediapolis. Cambridge: Polity: p. 57.

2. Kellner, D. (2003). Media spectacle. London: Routledge. 
I will discuss this form of interaction between media and justice by using Laclau and Mouffe's discourse theory. ${ }^{3}$ Building upon the work of Foucault, Laclau and Mouffe radicalize the notion of discourse. Whereas the former differentiates discursive from non-discursive social constructions, Laclau and Mouffe argue that social practices are always and completely discursively constructed, as articulation is confined to discourses:

The fact that every object is constituted as an object of discourse has nothing to do with whether there is a world external to thought, or with the realism/idealism opposition. An earthquake or the falling of a brick is an event that certainly exists in the sense that it occurs here and now, independently of my will. But whether their specificity as objects is constructed in terms of 'natural phenomena' or 'expressions of the wrath of God', depends upon the structuring of a discursive field. What is denied is not that such objects externally to thought, but the rather different assertion that they could constitute themselves as objects outside of any discursive conditions of emergence. ${ }^{4}$

Thus, discourses are ever-present in the social field: they form a relational system of meaningful practices, or as Derrida would put it: 'everything becomes discourse'. ${ }^{5}$ As a result Laclau and Mouffe reject the notion of determinism: subject positions shift with changes in context. This opens up the possibility of seeing discursive constructions in terms of constant struggles for hegemony as absolute fixation of meanings will never be achieved. To understand the absence of both absolute fixation and absolute non-fixation (as the latter would indicate psychosis instead of discourse) they introduce the concept of 'nodal point':

[...] order - or structure - no longer takes the form of an underlying essence of the social; rather, it is an attempt - by definition unstable and precarious - to act over that 'social', to hegemonize

3. Laclau, E. (2004). Ethics, normativity, and the heteronomy of the law. In S. Cheng (ed.). Law, justice, and power. Between reason and will. Stanford: Stanford University Press.

4. Laclau, E. \& Mouffe, C. (1985). Hegemony and socialist strategy. Towards a radical democratic politics (p. 108). London: Verso.

5. Derrida, J. (1978). Writing and difference. London: Routledge. 
it. [...] the social always exceeds the limits of the attempts to constitute a society. At the same time, however, that 'totality' does not disappear. If the suture it attempts is ultimately impossible, it is nevertheless possible to proceed to a relative fixation of the social through the institution of nodal points. ${ }^{6}$

In this sense, nodal points are identifiable points of reference that lend temporary stability and coherence to a discourse. A discourse finds its limits by excluding 'radical otherness': that which has nothing in common with the differential system that induces exclusion. It works through what Laclau and Mouffe call the 'logic of equivalence', which is an equalization of discourses $(\mathrm{A}=\mathrm{B}=\mathrm{C})$ by opposing it to the negative discourse of an 'outside' (D): $A=B=C \neq D$. As a result the differences between the 'chain of equivalence' (the differences between A, B, and C) are weakened with respect to D. The 'outside' (D) is both constitutive of discourses and identities and a threat (as it prevents discursive construction from completion). Thus, Laclau and Mouffe's emphasis on discursive struggles for hegemony and completion is what makes their discourse theory particularly appropriate to research conflict and identity (politics), ${ }^{7}$ as is the case with the trial against Van Anraat.

Dutch businessman Frans van Anraat is amongst other things charged with complicity in the genocide of Iraqi Kurds by Saddam Hussein's regime. After the fall of the Iraqi dictator, Frans van Anraat was tried in The Netherlands and sentenced to 17 years imprisonment. Prior to and during the trial the media played a crucial role in its classical function of channeling information aswell as in (co-)directing the legal process. The strategic employment of media to influence the Van Anraat trial makes this case appropriate for analysing the functioning of 'media/trial', the interaction between media and justice. Before I discuss the strategic employment of media, I shall firstly discuss the genocide of the Kurds and the trial against Frans van Anraat in this introductory section. In the following paragraphs I shall demonstrate the functioning of 'media/trial'.

6. Laclau, E. \& Mouffe, C. (1990). Post-Marxism without apologies. In E. Laclau (ed.) New reflections on the revolution of our time (p. 90-91). London: Verso.

7. Carpentier, N. \& Spinoy, E. (eds) (2008). Discourse theory and cultural analysis. Media, arts and literature. Creskill: Hampton Press. 


\section{The Kurdish genocide}

Businessman Frans van Anraat is suspected of supplying large quantities of raw materials required for the production of poison gas by the Iraqi regime in the 1980's. From 1980 to 1988, Iraq and Iran were at war with each other. The Iraqi leader Saddam Hussein believes that its Kurdish population (who live in oil-rich northern Iraq) are sympathetic to Iranian soldiers and Peshmerga (Iraqi insurgent). To discourage the Kurdish civilian population, an extensive operation is set in motion; Al-Anfal (known in English as Anfal campaign) is the term with which the Iraqi regime denotes the plan to terrorize the Kurdish population. The infamous leader of the Anfal campaign is Ali Hassan al-Majid, known in the West as 'Chemical Ali'; this cousin of Saddam Hussein received his nickname after the poison gas attacks that he had carried out on Kurdish citizens and Peshmerga, and on Iranian soldiers. Human rights activists denounced the poison gas attacks as genocide at an early stage, ${ }^{8}$ but only until the trial of Van Anraat (in December 2005) it was legally established that a genocide had actually taken place. The outcome of the trial against Frans van Anraat is important because, since it it had now been legally established that the genocide had occurred, accusations of 'genocide' could also be made in the trials against Saddam Hussein and Ali Hassan al-Majid.

\section{Legal prosecution of Frans van Anraat}

The journalist Arnold Karskens, who has done much research on businessman Frans van Anraat, states: 'Frans van Anraat ... is the biggest war criminal The Netherlands has ever known'. ${ }^{9}$ He has for example been held responsible for delivering more than $60 \%$ of Iraq's POC13 imports, a raw material used in the poison gas Tabun.

In 2003 Frans van Anraat, yet a free man, holds interviews with amongst others Alexander Münninghoff, an undercover secret service informer operating as a journalist. ${ }^{10}$ Münninghoff states that he, at the request of the Dutch

8. Human Rights Watch (July 1993). Genocide in Iraq: The Anfal Campaign Against the Kurds. Available at: http://www.hrw.org/legacy/reports/1993/Irakanfal/

9. Karskens, A. (2006). Geen cent spijt. De jacht op oorlogsmisdadiger Frans van Anraat. Amsterdam: Meulenhoff: p. 186.

10. Münninghoff, A. (2003). Vluchten in wroeging. Haagse Courant, 10 May. 
secret service (AIVD: General Intelligence and Security Service), has a major newspaper interview with Van Anraat. ${ }^{11}$ The interview leads to furthur talks with other magazines and television shows. These catch the attention of the Dutch Public Prosecution Service and the former businessman is arrested on December $6^{\text {th }} 2004$.

Van Anraat is arrested in his home in Amsterdam, which on December $17^{\text {th }}$ of that same year, becomes known as a 'safe house' of the secret service: Van Anraat was an informer of this service. This raises the peculiar situation that a citizen whilst working for a powerful state department, namely the secret service (that had brought Van Anraat into publicity by requesting the journalist and informer Alexander Münninghoff to generate media attention) is facing prosecution from another state department, namely the Public Prosecution Service. The secret service had also enabled Van Anraat's possession of travel documents six weeks prior to his arrest. However, the risk of him escaping led to his immediate arrest and later to a trial.

In court the public prosecutors state: '[...] the activities of the accused in 1988 and 1989 leave no doubt that the accused without hesitation functioned as main purveyor for a genocidal regime'. ${ }^{12}$ On May $9^{\text {th }} 2007$ the verdict of the appeals process is announced: Frans van Anraat receives an extra two years and is sentenced to 17 years imprisonment. The genocide-charges remain unchanged: the attacks on the Kurds is legally recognized as genocide, but Van Anraat is not complicit in genocide. The increased sentence is related to the charges for war crimes: he is found guilty of complicity in multiple war crimes, which explains the additional two years on top of his previous imprisonment charges.

\section{Expert interviews}

Many people were involved in the prelude to and the legal settlement of the lawsuit against Frans van Anraat: the journalists that interviewed him, the politicians who did or did not impose obstacles to prosecute him, the victims who with the aid of a lawyer testified of their suffering, lawyers who stood by Van Anraat during the indictment process, and the public prosecutors who prosecuted him. All these people used the media to advocate their interests.

11. Alexander Münninghoff. Interview with author, 22 October 2009.

12. Public Prosecution Service (2005). Closing argument. $N^{\circ}$ 09/751003-04. 
They have all done so in different ways. To analyse how the stakeholders in the process against Frans van Anraat used news media, I have held semistructured interviews with the following persons:

Name and Function

Amir Khadir: Chairman Halabja Committee (Kurdish genocide victims organization). ${ }^{13}$

Liesbeth Zegveld: Lawyer of the Halabja Committee.

Alexander Münninghoff: Journalist and Dutch secret service (AIVD: General Intelligence and Security Service) informer. He published a newspaper interview in which Frans van Anraat could tell his story unhindered.

Ronald Sistermans: Television journalist who broadcast a critical interview with Van Anraat.

Arnold Karskens: Investigative journalist who since Van Anraat's recidency in Iraq has publicized and criticized him.

Jan Peter van Schaik: Lawyer of Frans van Anraat.

Ruud Gijsen: Lawyer of Frans van Anraat.

Harry van Bommel: Member of the Dutch House of Representatives (Socialist Party); a politician who has advocated for charges against Van Anraat.

Krista van Velzen: Member of the Dutch House of Representatives (Socialist Party); a politician who has advocated for charges against Van Anraat.

Anonymous: High ranking employee of the Dutch Public Prosecution Service; directly involved in the case against Van Anraat.

The extensive stakeholder interviews were held either once or several times: on average the interviews lasted approximately one hour. Most interviews were held face-to-face, a few were held by telephone. The interviews were recorded and later transcribed in order to analyse them according to Laclau and Mouffe's discourse theory. ${ }^{14}$ In the next section the interviews and analysis shall be discussed.

\footnotetext{
13. The Halabja Comité has e.g. supported the interests of victims in het trial, supplied the Public Prosecution Service with Iraqi documents and translated Iraqi language videos.

14. Laclau, E. \& Mouffe, C. (1985). Hegemony and socialist strategy. Towards a radical democratic politics. London: Verso.
} 


\section{Media use}

\section{Two groups involved}

Based on their use of media ('articulation' in discursive terms) the respondents can be divided into two groups that function as 'social antagonists'. The first group consists of the victim's spokesman, lawyers (of both the victims and the accused) and journalists (both the secret service informer as well as the other journalists). This mixed group views media as an information channel; dealing with the media is based on the premise that media are the guardian of truth and justice.

The second group consists of the people from the Public Prosecution Service and members of the Dutch House of Representatives (= Lower House). This group understands media to be a tool that can be applied to shape trials: during the trial this group applied media strategies to give direction to the process in the case against Van Anraat (in both moral and legal sense), how the events underlying the lawsuit must be seen, what the construction of criminality in this case is, where responsible lie etc. These media strategies have, as was intended, helped to shape the legal process.

In the following paragraaf I shall discuss the two groups, their views on and their use of the media. I shall start with the second group as news reports were most actively shaped by the individuals from this group; they employed media strategically to steer lawsuits.

\section{Media as designer of a legal process}

The second group consists of indivduals who consider media as a means to shape lawsuits. Of those interviewed this concerns members of the House of Representatives Harry van Bommel and Krista van Velzen and above all the anonymous high-level employee (hereafter called Anonymous) of the Public Prosecution Service. The Prosecution has a professional relationship with media: media strategies are employed in large (criminal) cases. Anonymous characterizes the case against Van Anraat as atypical by firstly describing the use of regular media strategies. In normal cases, the use of media is for instance effective when little evidence is at hand, so as to increase the pressure:

[Author: Sometimes lawyers go to the television show Nova because they know that the judges are watching] Yes, but I go [to 
the newspaper] 'De Telegraaf' because I know that police offcials and criminals read 'De Telegraaf' on Saturday. So I go to 'De Telegraaf'... With [an unnamed lawsuit] for example, we had a difficult task ... with criminals testifying as witnesses... - there was no jurispudence on that aspect, there was nothing. That means you pressure the ... This was a lawsuit actually only dealing with hashish. Organized crime with hashish, it was not a multiple murder trial... [i.e. a relatively 'light' case]. This means that you as a prosecutor, besides making heavy charges, you need to frame the case to the most influential parties. The pressure on the court is increased by the prescence by cameras and journalists. If there is a live report from Twan Huys from NOVA on the Parnassusweg [the location of the court] every day... So if you have a difficulty with the evidence you must increase the pressure on the case as it also puts pressure on the judge. And if there is a lot of pressure, a judge will be more inclined to give the public prosecutor the benefit of the doubt. ${ }^{15}$

Increasing pressure on judges to reach a high sentence is a continuation of creating sentiments in the media. But well developed attention may also have additional consequences: it could, for example, aid in recruiting (criminal) witnesses:

Criminal witnesses come on board when: there are people in organized crime that will only talk if they think the person they're talking about is interesting enough. Because if the person they're talking about is interesting, they also become interesting with their own story - it is self-interest. Thus in major criminal cases with problematic evidence, you create evidence by framing them in the media, by positioning them. ${ }^{16}$

Potential criminal witnesses are not thus not asked to serve a higher purpose (e.g. serving the public with a testimony), but with the more realistic idea of serving their own interests; there is 'no place for naïvety' when recruiting (criminal) witnesses. But a defendant can usually also be thwarted in other

15. Anonymous. Interview with author, 29 May 2009.

16. Anonymous. Interview with author, 29 May 2009. 
ways. Logically criminals do not wish their activities to see the daylight; doing business with a person with much media attention is therefore undesirable. The result is that a person that is at the centre of much media attention is isolated from his criminal network. It could therefore be beneficial to represent a person as the master criminal:

... I [have] experienced that it is highly effective to make a major criminal out of someone in the media. You isolate someone from his group: once the media follow him other criminals can hardly do business quietly with this person. Because they and their criminal network would in turn get exposed as well. The person does get an aura of indefeasibility but that just makes him more vulnerable and easier to get.$^{17}$

In discursive terms this can be understood as A (criminal) $=\mathrm{B}$ (criminal network), until a 'constitutive outside' $(\mathrm{C}=$ media) is brought in, which changes the equation into $\mathrm{A}=\mathrm{C} \neq \mathrm{B}$.

According to Anonymous the strategic employment of media aimed at thwarting a persons criminal activity works with professional criminals. This is in contrast to suspects of isolated crimes, like a crime of passion. In the words of Anonymous:

Well, with homicide it's a different story. But organised crime, arms trafficking, smuggling, threats: in general, the fact is committed and as a prosecutor you need to provide evidence. This is not a debate about: 'did this really happen?' It is not the Putten murder case [an example of an isolated crime]: then you don't do this, as it wouldn't work properly, it would back fire on you. Thus prosecutors who have done that in other cases ... with isolated murder cases, for example, it didn't work. But in homicide cases, execution cases ...

[Author: so it works with crimes that continue?]

In a continuing process. You also have to discontinue that process. Thereby you're stopping the acts of a person or group. You're also making it difficult [for him/them]. ${ }^{18}$

17. Anonymous. Interview with author, 29 May 2009.

18. Anonymous. Interview with author, 29 May 2009. 
This strategic use of media, as stated, can be applied to regular major criminal cases. The lawsuit against Van Anraat is in that respect atypical: it differs because it does not involve continuing criminal activities (the case that was brought against him dated from the 1980's) and because no witnesses from the criminal network were recruited: the witnesses are victims from Iraq and Iran who report the chemical weapons attack on their family, friends, livestock, crops, drinking water, etc. These are not people who only speak to be considered interesting to others ('Witness QUMARZ (G64) was out of town when the bombs fell. When he went back into the town to go to his familiy he was confronted with terrible images ... Witness found 21 of his relatives dead. Many bodies were covered with blisters.' ${ }^{19}$ ). Yet media were important in forming the case: "What ... could happen is that a journalist starts digging, bumps into a witness and that you then get the witness. Do you understand a bit how that process works? An indirect process." 20

Besides recruiting witnesses media attention also led to the fact that priority was given to the case against Van Anraat. Before Frans van Anraat became an official suspect he appeared in the current affairs program 'Netwerk'.

If you appear on the Internet [as a criminal] it is not so bad, newspapers are a bit worse - and then it also depends on which newspaper it is: [quality newspaper] NRC is less of a problem [to criminals] than [popular newspaper] Telegraaf.

[Author: because De Telegraaf is more sensational?] Yes, and it has a higher circulation, that is also a problem. And there is a medium that has much more impact and that is what he [Van Anraat] has done, and that's TV. He has done [TV program] Netwerk and that is TV that reaches a lot of viewers.

[Author: so it's more about the number of viewers?]

Yes, and [which channel] broadcasts it and the chance that people such as the police chief at the time, Martijn van der Beek, and myself watch it. ${ }^{21}$

19. Public Prosecution Service (2005) Closing argument. $\mathrm{N}^{\circ}$ 09/751003-04. Name of witness in capitals: in original.

20. Anonymous. Interview with author, 29 May 2009.

21. Anonymous. Interview with author, 3 July 2009. 
After seeing the show about and with Van Anraat it was decided that a legal investigation would be started [the question of why Frans van Anraat 'voluntarily' held a television interview will be discussed later].

But not only Anonymous has actively employed media strategies: members of the House of Representatives also do this. Harry van Bommel (Socialist Party) states that representatives in general need media to justify questions for ministers:

[W]hen you have knowledge of a fact that has not been in the news, it is very difficult to request a minister on his point of view. Because then the minister retaliates with, and this is actually an unwritten rule in the House of Representatives: what is your question based on? ${ }^{22}$

Therefore it is necessary, if you wish to address something in the political arena, to support this with news media. But the reverse is also possible: asking political questions with the goal to generate news items that can be used by others. In the words of Van Bommel: “... you address it politically, this in turn leads to new publications with which one can make a case....". ${ }^{23}$

As such Krista van Velzen (Socialist Party) knew that her questions addressed to the minister could possibly be of importance for the case against Van Anraat:

[Author: during the legal investigation you questioned the minister, for example about the laissez-passer for Syria for Van Anraat. Did you at that time know how important that information would be?]

Yes, yes. Certainly. But that is a sort of gut feeling. You never know what will cause problems for someone [i.e. Van Anraat], but at the time I really thought: what we are doing here has nothing to do with answers from the minister, but is what the judges will see. ${ }^{24}$

The disclosure of such information is in the case of Van Anraat even more crucial: Frans van Anraat was in contact with the secret service, because of

22. Harry van Bommel. Interview with author, 21 April 2009.

23. Harry van Bommel. Interview with author, 21 April 2009.

24. Krista van Velzen. Interview with author, 22 December 2009. 
which the case had political dimensions. The secret service does not disclose information without coersion; making the information public by demanding answers to questions of members of the House of Representatives is thus of great value. Here, the logic of equivalence comes into play again: A (Public Prosecution Service $)=$ B (members of the House of Representatives $) \neq$ Van Anraat, even though the legal and political principle of separation of powers would assign different roles to A and B. Moral principles in this case function as a nodal point, tying A and B to the same discourse, as Van Anraat serves the role of a constitutive outside.

Van Velzen has great awareness of the potential impact of publications of her questions and the answers to them. But utilization of media means not only that as much as possible must be made public, but rather that at times something is not made public:

I would have welcomed further research by the Public Prosecution Service on other companies [suspected of illegal trading with Saddam Hussein] to estimate if prosecution was possible. And I have not voiced myself in the trial period of Van Anraat because I thought that it could strengthen the defense in saying: look, it's not fair [that only Van Anraat is put on trial]. It was their [the defense's] main point: that they were victimized and that it was not fair because they were the only ones. That's why I never added fuel to the fire because before you know that man is acquitted or gets reduced sentences or whatever.

[Author: because they could then use your statements in the media in their defense]

Yes, and especially if there is a response from the Cabinet with which they can do something. ${ }^{25}$

In the case of Frans van Anraat we see that high-level employees of the Public Prosecution Service and members of the House of representatives have strategically employed media with the aim of achieving a legal conviction. (That could be indirectly, such as when seeking potential witnesses.) Also, media have (in the form of the television show 'Netwerk') given the legal investigation a startup moment, information has been disclosed by a minister after parliamentary questions and possible arguments for the defense were

25. Krista van Velzen. Interview with author, 22 December 2009. 
kept outside the media by introducing a 'period of silence'. More media stratgies exist but are inappropriate to discuss here - For more media strategies in lawsuits, see e.g. Leurs (2011).

\section{Media as an information channel}

In contrast to the above persons, there is also a group of stakeholders who have based their actions on the belief that media are not tools in legal struggles, but 'only' guardians of truth and justice. Remarkably, this latter group consists of persons with conflicting interests: the victim-spokesman and his lawyer, Van Anraat's lawyers, and journalists, including the secret service informer. As far as their interests are concerned they are positioned as $\mathrm{A}$ (spokesman and lawyer) $\neq \mathrm{B}$ (Van Anraat's lawyers) $\neq \mathrm{C}$ (journalists), but when their beliefs about the relation between media and justice become a major factor the chain of equivalence changes into $\mathrm{A}=\mathrm{B}=\mathrm{C}$. I will therefore now discuss their beliefs.

During the trial the victims had an opportunity to speak; they were represented by Amir Khadir (chairman Halabja Committee) and Liesbeth Zegveld (lawyer Halabja Committee). Khadir indicates that initially Zegveld was also their spokesperson in the media, but that he then took over as the media 'were very much looking for real victims, for real people who had experienced the use of chemical weapons'. ${ }^{26}$ According to him the media in The Netherlands function well: they are more fair and professional, and less politicized than what he has experienced in other countries (including Iraq). Their coverage is accurate throughout all media forms and titles. However, he points out a difference in interest in the trial between Dutch media: 'For instance, if you look at De Telegraaf [a popular newspaper]: I think they only took two trips to The Hague [the city where the trial was held]. And they've also had contact over the phone just a few times. So they have not properly reported the case'. ${ }^{27}$ This is contrary to newspapers like de Volkskrant that have paid much more attention to the case. In short, in contrast to foreign media Dutch media according Khadir report accurately about the trial, although they differ in the degree to which they turn their attention to it.

26. Amir Khadir. Interview with author, 25 March 2009.

27. Amir Khadir. Interview with author, 25 March 2009. 
The victim's lawyer, Liesbeth Zegveld, is partly of the same opinion, but she comes to more complex conclusions about the functioning of media. She states that media representations were accurately: 'I can say that in this case it went pretty well. The attention Nova [a highbrow current affairs program] has had for the background [of the trial] was okay; in that sense they have done their best ${ }^{28}$, just like NRC [a quality newspaper] also meets her criteria. ${ }^{29}$

Yet, media in general don't provide a good view on legal issues: the media are 'not so well at home in legal developments'; they are, for instance, more interested in suspects than in victims [Zegveld predominantly acts as a lawyer for victims]. ${ }^{30}$ If she herself acts in the media she has to adapt: "As an expert you try to tell a simplified version.' ${ }^{31}$ Her use of media is limited to expressing the views of her clients, it does not serve a direct legal purpose. Yet media attention can have a preventive effect:

These are cases [trials] that affect society. ... [For] a preventive effect of such a trial, it must be known. If nobody knows that it is being conducted then the preventive effect is not so great. Media appearance can help. If there are other cases arising from it the seeds are sown. [You can then] make other clients aware of the opportunities that exist. Following those interviews a lot of victims report [for other trials]. ${ }^{32}$

In short, according to lawyer Zegveld media have been accurately in this case, although it may be different in other cases. The only way media can function as an instrument is in prevention and as a stepping stone to other cases.

The beliefs of the lawyers of Frans van Anraat, Jan Peter van Schaik and Ruud Gijsen, are in line with those of Zegveld. According to Van Schaik media in general are not always precise when it comes to legal developments. ${ }^{33}$

Lawyers, at least as far as the interviewed persons are concerned, share the belief that media don't report enough from the perspective of legal discourses,

\footnotetext{
28. Liesbeth Zegveld. Interview with author, 6 May 2009.

29. Liesbeth Zegveld. Interview with author, 6 May 2009.

30. Liesbeth Zegveld. Interview with author, 6 May 2009.

31. Liesbeth Zegveld. Interview with author, 6 May 2009.

32. Liesbeth Zegveld. Interview with author, 6 May 2009.

33. Jan Peter van Schaik. Interview with author, 14 August 2009.
} 
although there is some praise for NRC. But media attention is also considered not to be of great importance:

In The Netherlands a trial takes place inside a courtroom. We may assume that judges also read newspapers, but judges are professionals so they will be able to filter. A case takes place inside a courtroom. ${ }^{34}$

Attention in the media is not in the interests of the trial and not in the interest of clients, although it can make good advertising for lawyers. But this exceeds an ethical boundary, according to (Van Anraat's lawyer) Gijsen. ${ }^{35}$ The lawyers of Van Anraat see no instrumental or ethical value in the use of media for their cause. However, the functioning of media in this particular case has surprised them: there seemed to have been something going on in the background. For instance, there was a moment when they would get clarity on the relationship of journalist Alexander Münninghoff with the secret service. Van Schaik states:

And then we said: now we want to question that AIVD [the secret service]. And ... what surprised me: Teeven [the public prosecutor in this case] jumped up, the doors were closed immediately. And there were journalists in the courtroom and except for a very small piece in the NRC nothing was reported about it. ... I had expected the newspapers to be full of it, [but] it all stayed incredibly quiet. ... I can only guess. Is this self-censorship, or did someone from the Public Prosecution Service ask to keep this quiet? I don't know. ${ }^{36}$

There are more media-related situations that have puzzled Van Anraat's lawyers. E.g. there is the role of the interview with Network in the legal dossier. In this television interview Frans van Anraat makes self-incriminating statements, after which a judicial inquiry into his doings is started (and which leads to the trial against him). The reason for this interview has always been a source of speculation.

34. Ruud Gijsen. Interview with author, 3 September 2009.

35. Ruud Gijsen. Interview with author, 3 September 2009.

36. Jan Peter van Schaik. Interview with author, 14 August 2009. 
[W] hat is central to this case is, of course, the interview the client has held [with Network] and which was used in the dossier as a starting point for suspecting him. ... [W]e have always said: 'Yes, Van Anraat was led into this. The interview has been designed to give Justice that starting point. ${ }^{37}$

Besides the silence in the media about the role of the secret service and speculation about the reason for the Network interview, there is a third mediarelated issue that has puzzled Van Anraat's lawyers. This is an interview with Ichiro 'Charlie' Tanaka, a former Japanese business associate of Van Anraat who acts in this trial as witness for the Prosecution.

... Tanaka, that was a very important witness. And that's again very remarkable that, I think it was [current affairs program] Nova, already had some sort of interview with him shortly before he was about to testify. You know that there are hidden agendas. But you also know that a journalist just might have an interview with someone who may act as a witness. What can you do about it ? $^{38}$

We have now have a situation where Van Anraat's lawyers on the one hand believe that media play no role in legal processes and on the other hand are confronted with what are held to be remarkable media-related events. And then media indeed appear to have been of interest. According to Gijsen the 'normal' situation would be A (justice) $\neq \mathrm{B}$ (media), but he now sees himself confronted with an $\mathrm{A}=\mathrm{B}$ situation. For example, they found that it was difficult to find witnesses for the defense:

People are cautious, as they do not like to get involved in such a case. The North American experts were also cautious. Because Van Anraat was also on CNN, so they have heard of him. ... We have spoken with people who say, "You do have a point there, but I cannot state anything officially about it'. Then, as a lawyer, you should put that to rest and say nothing about it. ${ }^{39}$

37. Jan Peter van Schaik. Interview with author, 14 august 2009. Van Schaik nuances this by acknowledges that ultimately he has not been able to find out the reason(s) for Van Anraat's appearance in Netwerk.

38. Jan Peter van Schaik. Interview with author, 14 August 2009.

39. Ruud Gijsen. Interview with author, 3 September 2009. 
Thus, the experience of Van Anraat's lawyers contradicts their assumption: where media are supposed to play no role, this case has shown them differently. This discrepancy cannot simply be nullified by adopting another attitude towards the role of media: interference in media affairs require manpower, which is almost impossible for lawyers who are provided (and paid) by the state (as with Van Anraat).

Van Anraat's television interview with Network was the starting point for the legal investigation. Network builds on an earlier interview in the newspaper Haagse Courant by journalist and secret service informer Alexander Münninghoff. Münninghoff also facilitated the Network interview by organising it, and by providing his private house as an interview location.

Münninghoff has been a journalist for a long time, among others in the former Soviet Union, and provided the secret service additional information occasionally. He was not part of the secret service's staff, he was an informer. ${ }^{40}$ Shortly before his retirement as a journalist, Van Anraat would be his last case, he obtains 'useful' information again - this time in the form of a telephone number that turned out to belong to Frans van Anraat. In an anonymous phone call, which Münninghoff considered to have come from the secret service, he was asked if he was interested in an interview with Van Anraat. 'I got that [phone] number, which I then called. We [Münninghoff and Van Anraat] made an appointment at the Kurhaus hotel. We've had a talk for three hours, I think.' ${ }^{41}$ Münninghoff's reason for conducting an interview with Van Anraat is a continuation of his conception of media as a channel of information:

I gave him guarantees that ... he was also allowed to read it first, which I always do with important interviews - I'm not biased, my whole life I've tried, although that is impossible, to remain objective. And to give someone the right exposure. If you're going to add all kinds of insinuations, than that is not the correct profile. So I let him present his story in a detailed way, at least for a page and a half..$^{42}$

Ultimately, this newspaper interview, as we saw before, lead to the television interview for Network, which in turn is the starting point for the legal

40. Alexander Münninghoff. Interview with author, 22 October 2009.

41. Alexander Münninghoff. Interview with author, 22 October 2009.

42. Alexander Münninghoff. Interview with author, 22 October 2009. 
process. Münninghoff's work was based on the idea that media are able to give a correct representation of a certain situation. But to him it's not clear what the reason is for the secret service to encourage Van Anraat to appear in the media. There are four possibilities: the secret service wanted to end all speculations about Van Anraat, Van Anraat had to serve as an argument for the (political) position that Iraq possessed weapons of mass destruction, making Van Anraat visible to the outside world could be have been a first step to request a larger budget for secret service field workers, or the fall of Van Anraat was a gesture towards Kurds living in The Netherlands or (other) Muslims or to the foreign political and/or legal world. In any case, the secret service put Van Anraat in the spotlight:

[I]n that TV interview [with Netwerk] at my house. He responds to the question ... the interviewer asks: 'Aren't you afraid of action from the side of the government?' 'No, no.' He asks this twice. Then he [Van Anraat] talks his way out of it. He has his reasons for doing so. So in hindsight: the secret service has given him the assurance 'There is nothing wrong with you, nothing will be a threat to you'. ${ }^{43}$

The intrigues of the secret service and the course of the legal process are reasons for Alexander Münninghoff to characterise the trial against Van Anraat as 'an obvious show trial'. 44

The television interview for Network has been held by journalist Ronald Sistermans. He knew Alexander Münninghoff from the time he did a report on the 'Russia club' for a different current affairs program: the 'Russia club' is a group of trained secret service informers. ${ }^{45}$ The Netwerk interview with Van Anraat was conducted in Münninghoff‘s home. ${ }^{46}$

In the Network interview Van Anraat's 'thumbscrews' were tightened: after a few exploratory questions the interview became very sharp, verging on becoming aggressive. Thereby 'instantly it became clear that this was someone who might have blood on his hands'. ${ }^{47}$ Sistermans chose this approach

\footnotetext{
43. Alexander Münninghoff. Interview with author, 22 October 2009.

44. Alexander Münninghoff in an email to auteur, 4 September 2009.

45. Ronald Sistermans. Interview with author, 2 February 2010.

46. Ronald Sistermans. Interview with author, 2 February 2010.

47. Ronald Sistermans. Interview with author, 2 February 2010.
} 
because he was under the impression that Van Anraat did not tell the truth before: he must have been involved in some shady business. In short, Sisterman's interview for Network had a very different tone than the previous interview by Münninghoff for the newspaper Haagse Courant. But Frans van Anraat took no offense to the much more critical television interview:

[I] think he was under the impression ... that he was in a fairly unassailable position, for he had the idea - this is a bit of thinking out loud, though - I think Van Anraat was at that time under the impression that he was protected by the Dutch government. He was also in a 'safe house', so from this I can imagine that he thought: 'well, I have Münninghoff's trust and, yes, there's a reporter here [Sistermans] that is critical of me but it won't hurt if I say "I knew really nothing about it",. ${ }^{48}$

The interview with Van Anraat was an extraordinary opportunity for Sistermans: there is a very suspicious person who still wishes to speak openly. Sistermans has held the interview with the intention of "just getting out the truth ... It is more like: it is remarkable that we're able to interview this man, it would be even more special if we can, well, get him to say something newsworthy.' ${ }^{49}$ The idea that Sistermans might thus have acted in the interest of the secret service played no role for him. In reflections on the case afterwards, the interests of the secret service have been of concern to him: 'well, I have of course wondered about it several times. Actually, as a journalist I've been used by the secret service ${ }^{50}$. In discursive turns this plays out as $\mathrm{A}$ (journalist $)=$ $B$ (secret service) because $C$ (Van Anraat) serves as antagonist $(A=B \neq C)$.

The prominent role of the interviews by Alexander Münninghoff and Ronald Sistermans seems to overshadow the work of Arnold Karskens. But Karskens, with his form of investigative journalism, has spent much more time and attention to Van Anraat: several years prior to the trial, Karskens wrote about him, resulting in the book 'Geen cent spijt. De jacht op oorlogsmisdadiger Frans van Anraat' ['Not a penny of regret. The hunt for war criminal Frans van Anraat'] (Karskens, 2006). Karskens claims to have two motives to spend years of journalistic research in general and on Van Anraat in par-

48. Ronald Sistermans. Interview with author, 2 February 2010.
49. Ronald Sistermans. Interview with author, 2 February 2010.
50. Ronald Sistermans. Interview with author, 2 February 2010. 
ticular: 'a good journalistic story' and 'moral indignation' ${ }^{51}$. As a journalist he views the conviction of Van Anraat therefore as 'a good result' 52 . Yet he distances himself from certain aspects of investigative journalism: 'too much obstinacy decreases your own joy of life ${ }^{53}$. But besides the journalistic and moral motives that he acknowledges he pays some attention to the wider implications of making cases public. Thus in hindsight he suspects Van Anraat was victimized by the secret service in order to make a case for the possible presence of weapons of mass destruction in Iraq. ${ }^{54}$

But this last reflection of Karskens is an exception: all persons from this group (besides Arnold Karskens: Amir Khadir, Liesbeth Zegveld, Jan Peter van Schaik, Ruud Gijsen, Alexander Münninghoff, and Ronald Sistermans) have only seen Frans van Anraat as a former trader in chemicals who may have conducted illegal businesses. They have not addressed possible wider interests of exposing Van Anraat in the media: the media are primarily considered to be channels of information. Thus, $\mathrm{A}$ (media) $\neq \mathrm{B}$ (justice). The opposite view $(A=B)$ is held by the previously discussed group: the anonymous high ranking employee of the Public Prosecution Service and the two members of the House of Representatives, Harry van Bommel and Krista van Velzen, see media as a tool that can be applied to shape legal processes in general and trials in particular.

The interference of media with law can be possitive - in the Conclusion I will expand on it's ethical desirability vs. undesirability. In the case of Van Anraat there remains a twofold judgment: on the one hand, the use of media helped in condemning a man who outside the legal circles was already suspected to have been involved in illegal businesses (for instance in Karskens journalistic reports). On the other hand the focus has been on Van Anraat, while the illegal businesses was also committed or facillitated by numerous companies and governments. As such, the then Dutch Secretary of State for Foreign Trade Frits Bolkestein and USA special envoy Donald Rumsfeld had encouraged trade with Iraq earlier, even when within the Dutch Ministry of Foreign Affairs there were doubts about the Saddam regime. The encouragement of trade was picked up by companies from Singapore, Japan, the United

51. Arnold Karskens. Interview with author, 7 August 2009.

52. Arnold Karskens. Interview with author, 7 August 2009.

53. Arnold Karskens. Interview with author, 7 August 2009.

54. Arnold Karskens. Interview with author, 7 August 2009. 
States and The Netherlands (and possibly from other countries as well). ${ }^{55}$ And this was not only about illegal chemicals: also parts of plants for the processing of these chemicals are supposed to have been sold to Iraq. ${ }^{56}$ The disadvantage of abundant media attention for a certain person is that attention for others (people/companies/issues) seems to disapear. Media coverage in the event of litigation can thus be a double-edged sword.

\section{Media/trial}

There are two prominent and antagonistic views on the relationship between news media and justice. The most traditional is that of media as an information channel, as a 'sliding hatch' for truth. This is obvious in the largest group of respondents. In addition, we know from literature on other cases the 'trial by media' mechanism: media condemn suspects, without holding a direct relationship with law and justice. ${ }^{57}$ In other words, media and justice operate parallel to but independently of each other: $\mathrm{A}$ (media) $\neq \mathrm{B}$ (justice). This vision complements the use of 'litigation PR': the attempt to control the image of participants of lawsuits. ${ }^{58}$ The concept of 'trial by media' has been discussed and researched extensively elsewhere, e.g. by Santos \& Machado (2009), McLaughlin \& Greer (2011), and Simons (2009). But another view on the relationship of media and law exists: the relationship with the media by a group of respondents consisting of a high ranking member of the Public Prosecution Service and members of the House of Representatives can be seen as 'media/trial', i.e. the active employment of media strategies with the attempt to influence lawsuits. Where in 'trial by media' the media play a more or less independent role and where in 'litigation PR' the image is especially important, it is the legal shaping of a lawsuit by the use of media that is central to the concept of 'media/trial': A (media) = B (justice).

As the trial against Frans van Anraat has shown 'media/trial' can be effective. The question is whether this calls for a return to the media effects

55. Arnold Karskens. Interview with author, 7 August 2009. And: Karskens, A. (2006). Geen cent spijt. De jacht op oorlogsmisdadiger Frans van Anraat. Amsterdam: Meulenhoff.

56. Amir Khadir. Interview with author, 25 March 2009.

57. Chiasson, L.L. (ed). (1997). The press on trial. Crimes and trials as media events. Westport: Greenwood Press.

58. For instance: Levick, R. \& Smith, L. (2007). Stop the presses. The crisis and litigation $P R$ desk reference. Washington: Watershed Press. 
model: do theories about 'the effect/influence of media' become relevant again through this and other cases? My answer would be a clear 'no'. Media effect theories exist in different types, ${ }^{59}$ but all to some extent come down to the following reasoning: media (messages) are separated from a social context and viewed as 'cause', after which in 'society' a 'consequence' occurs. 'Media/trial' is not a return to these context free or context poor theories: 'me$\mathrm{dia} /$ trial' indicates active interaction with media by institutions and individuals who are faced with two issues: a competing system within justice and media, and a participatory media culture. Within justice and media there are many types of competitions: to have a person convicted or acquitted, a degradation or enhancing of reputations, viewer ratings, the hunt for scoops etc. These competitions are analogue to a capitalist system but do not merge together: where in capitalism the free market and profit are paramount, the struggles within justice and the (partly public) media are battles on their own grounds. Intensification of the competition on these battlefields is an explanatory context for the emergence of 'media/trial' principles and practices.

Another factor, as mentioned, is the major role of the growth of a participatory culture. Where in earlier times institutions occupied a role in the social field that was limited to their core expertise, there are now opportunities to not only be the object of reporting but to also help shape the message itself. This also extends to other fields: NGO's are nowadays not only the subject of news but cooperate in developing the most favorable coverage of their work or institution. In short 'media/trial' is not a return to the effects tradition or the idea of being activated through interests or a will to power, but can best be understood in the context of increased internal competition and a growing participatory culture. The legal and the media spheres are only two parts of our society where this mechanism occurs. 'Media/trial' is thus part of a relational discursive system.

The employment of media strategies to influence legal trials against suspects is not limited to The Netherlands: It occurs in countries such as the

59. Well known examples include: Althusser, L. (1998). Ideology and ideological state apparatuses. In J. Storey (ed.) Cultural theory and popular culture. A reader. $2^{\text {nd }}$ edition. Hemel Hempstead: Harvester Wheatsheaf. Klapper, J. (1960) The effects of mass communication. Glencoe: Free Press. McCombs, M. \& Shaw, D. (April 1972) The agenda-setting function of mass media. Public opinion quarterly, 36: 176-187. McLuhan, M. \& Fiore, Q. The medium is the message. An inventory of effects. New York: Bantam Books. 
United States and EU countries such as Italy. ${ }^{60}$ It is therefore appropriate to speak of a wide occurrence of a specific relationship between media and justice that can be termed 'media/trial'. As we have seen 'media/trial' differs from 'trial by media': where 'trial by media' refers to parallel but relatively independent discourses of media and justice, 'media/trial' indicates a more active employment of media strategies with the aim of influencing legal processes (usually in the form of trials).

Many conclusions can be drawn from the occurrence of 'media/trial'. Thus, the concept of 'justice' can be redefined, or the role of politics (or: politicians) in legal matters could be further considered. But I will limit myself here. 'Media/trial' operates, as mentioned before, in the context of both a competitive system of media (and justice) and an increased participation culture. This is exemplary of 'our time' and for countries where media and justice were previously seen as separate fields (mainly modern democracies). A new relationship must be found with this interaction between media and justice - the reversal of this development, e.g. with legislation, is in my opinion not an option given the wide cultural and social contexts within which 'media/trial' functions. In particulary it concerns journalists, lawyers of defendants of both individuals and companies. To begin with journalists: the negation (by journalists) that journalistic media are employed for the interest of others, in this case legal professionals and politicians, reveals a shocking naivety. This has its roots in the importance attached to 'objective reporting': by taking 'objectivity' as a starting point ('we only bring the news') there is no consideration of the broader context in which journalistic reporting works. While large parts of society (e.g. philosophy, media studies, law, etc.) have already put in question the idea of 'objectivity', it is time journalists also reconsider basic assumptions underlying their profession.

Finding new approaches to the changing relationship between media and justice is also important for lawyers and suspects. The concept of 'equality of arms' is of great value and means that in the various stages of the legal process, including any investigation that precedes the actual trial, the parties stand in an equal position. ${ }^{61}$ The lawyers of Van Anraat argue that there was

60. Anonymous. Interview with author, 29 May 2009.

61. Knoops, G.J. (2003). An introduction to the law of international criminal tribunals. A comparative study (p. 126). Ardsley, New York: Transnational Publishers. 
insufficient 'equality of arms' in this particular case. In the words of lawyer Van Schaik:

I don't think you want to know how much money this investigation has cost. The Public Prosecution Service that uses Wolterbeek, a former weapons expert [Cees Wolterbeek was a former UNSCOM inspector], as a consultant, while he also prepared an expert witness report. Then as a lawyer for someone who does not have the money, who does not have budgets ... then you are always a step behind. You do as much as possible to defend [the suspect] in every way and to employ own witnesses and experts. But there is no 'equality of arms'. ${ }^{62}$

If 'equality of arms' is of great value and turning back the occurrence of 'media/trial' is not an option, it follows that all participants in a legal process need access to media strategies that can improve their legal position. (In this regard Laclau and Mouffe note that an alternative for a dominant discourse - like any other alternative - is never non-discursive.) I will argue this point further by explaining why the use of media in court may even be desirable. I do this by discussing the differences between the concepts of the ethical and the normative order.

According to Ernesto Laclau (2004) the normative consists of rules of behavior (we usually call this 'morality') whilst the ethical is 'empty': unlike the normative the ethical does not consist of a set of concrete directions, but of abstract concepts for everyone to fill in, e.g. 'duty', 'justice', etc. The 'empty' ethical concepts are heterogeneous: they can be interpreted in multiple ways (in his discursive words: they can be fixated in multiple ways). It is exactly because of this 'emptiness' that the relation between the ethical and normative is contingent. If the ethical and normative orders would fully coincide, there is totalitarianism: instead of a continuing debate about the interpretation of ethical concepts such as 'justice' or 'duty' there would be timeless and comprehensive ethics/norms. The absence of a concrete basis for ethics is part of a democracy where multiple viewpoints have a place. In other words, the heterogeneity of ethics is why we do not live in a totalitarian society. From this it follows that defining ethical concepts and the choices for specific norms should never be left to a singular entity (i.e. a single institution

62. Jan Peter van Schaik. Interview with author, 14 August 2009. 
or person): forms of debate are essential to keep democratic values alive as, as we have seen in the above, alternatives to dominant discourses can never be non-discursive. In that sense, there can hardly be enough debate, also not in the media (provided that 'media/trial' functions in the context of a state of law; in nations where politics, media, and justice are ruled by one entity, there is of course little heterogeneity). ${ }^{63}$ In short, it is imperative that all those involved in legal disputes, including lawyers and defendants, are able to use media to strengthen their legal position: this contributes directly to an equality of arms and indirectly to a greater heterogeneity of social life. Of course there are many conditions attached, e.g. that media not only function in a homogeneous way and that all parties have equal access to media. But the principle stands: it is impossible to imagine 'our' current society without 'media/trial', making it important for journalists, lawyers and defendants to become familiar with this concept and possibly adopt media strategies themselves. The battleground of truth claims needs to be equally accessible by everyone.

\section{Bibliography}

Althusser, L. (1998). Ideology and ideological state apparatuses. In J. Storey (ed.) Cultural theory and popular culture. A reader. $2^{\text {nd }}$ edition. Hemel Hempstead: harvester Wheatsheaf.

Carpentier, N. \& Spinoy, E. (eds) (2008). Discourse theory and cultural analysis. Media, arts and literature. Creskill: Hampton Press.

Chiasson, L.L. (ed.) (1997). The press on trial. Crimes and trials as media events. Westport: Greenwood Press.

Derrida, J. (1978). Writing and difference. London: Routledge.

Hardi, C.H. (2011). Gendered experiences of genocide: Anfal survivors in Kurdistan-Iraq. Farnham: Ashgate Publishing.

Human Rights Watch (July 1993). Genocide in Iraq: The Anfal Campaign Against the Kurds. Available at: http://www.hrw.org/legacy/reports/1993 /Iraqanfal/

63. This does not produce complete arbitrariness: our thinking is limited by the prevailing social practices. Laclau, E. (2004). Ethics, normativity, and the heteronomy of the law. In S. Cheng (ed.) Law, justice, and power. Between reason and will (p. 183). Stanford: Stanford University Press. 
Human Rights Watch (11 March 1991). Whatever happened to the Iraqi Kurds? Available at: http://www.hrw.org/reports/1991/IRAQ913.htm\#4

International Center for Transitional Justice. Halabja Monument to Kurdish victims of gas massacre. Available at: http://memoryandjustice.org/site/ halabja-monument-to-kurdish-victims-of-gas-massacre/

Jørgensen, M. \& Phillips, L. (2002). Discourse analysis as theory and method. London: Sage.

Karskens, A. (2006). Geen cent spijt. De jacht op oorlogsmisdadiger Frans van Anraat [Not a penny of regret. The hunt for war criminal Frans van Anraat]. Amsterdam: Meulenhoff.

Kellner, D. (2003). Media spectacle. London: Routledge.

Klapper, J. (1960). The effects of mass communication. Glencoe: Free Press.

Knoops, G.J. (2003). An introduction to the law of international criminal tribunals. A comparative study. Ardsley, New York: Transnational Publishers.

Laclau, E. (2004). Ethics, normativity, and the heteronomy of the law. In S. Cheng (ed.) Law, justice, and power. Between reason and will. Stanford: Stanford University Press.

Laclau, E. \& Mouffe, C. (1985). Hegemony and socialist strategy. Towards a radical democratic politics. London: Verso.

Laclau, E. \& Mouffe, C. (1990). Post-Marxism without apologies. In E. Laclau (ed). New reflections on the revolution of our time. London: Verso.

Levick, R. \& Smith, L. (2007). Stop the presses. The crisis and litigation PR desk Reference. Washington: Watershed Press.

Leurs, R. (2011). Juridische PR [Litigation PR]. Den Haag: Boom.

McCombs, M. \& Shaw, D. (April 1972). The agenda-setting function of mass media. Public opinion quarterly, 36: 176-187.

McLaughlin, E. \& Greer, C. (February 2011). 'Trial by media'. Policing, the 24-7 news mediasphere and the 'politics of outrage'. Theoretical criminology, 15-1: 23-46.

McLuhan, M. \& Fiore, Q. (1967). The medium is the message. An inventory of effects. New York: Bantam Books. 
Münninghoff, A. (2003). Vluchten in wroeging. Haagse Courant, 10 May.

Public Prosecution Service (2005). Closing argument. No 09/751003-04.

Santos, F. \& Machado, H. (August 2009). The disappearance of Madeleine McCann. Public drama and trial by media in the Portugese press. Crime media culture, 5-2: 146-167.

Silverstone, R. (2007). Media and morality. On the rise of the mediapolis. Cambridge: Polity.

Simons, M. (March 2009). International crime tribunals and the media. Journal of international criminal justice, 7-1: 83-88. 